\title{
Social network analysis in international business research: An assessment of the current state of play and future research directions
}

Dol:

10.1016/j.ibusrev.2019.101633

\section{Document Version}

Accepted author manuscript

Link to publication record in Manchester Research Explorer

Citation for published version (APA):

Kurt, Y., \& Kurt, M. (2020). Social network analysis in international business research: An assessment of the current state of play and future research directions. International Business Review, 29(2), [101633]. https://doi.org/10.1016/j.ibusrev.2019.101633

\section{Published in:}

International Business Review

\section{Citing this paper}

Please note that where the full-text provided on Manchester Research Explorer is the Author Accepted Manuscript or Proof version this may differ from the final Published version. If citing, it is advised that you check and use the publisher's definitive version.

\section{General rights}

Copyright and moral rights for the publications made accessible in the Research Explorer are retained by the authors and/or other copyright owners and it is a condition of accessing publications that users recognise and abide by the legal requirements associated with these rights.

\section{Takedown policy}

If you believe that this document breaches copyright please refer to the University of Manchester's Takedown Procedures [http://man.ac.uk/04Y6Bo] or contact uml.scholarlycommunications@manchester.ac.uk providing relevant details, so we can investigate your claim.

\section{OPEN ACCESS}




\title{
Social network analysis in international business research: An assessment of the current state of play and future research directions
}

\author{
Yusuf Kurt • Mustafa Kurt
}

\section{This is an Author's Original Manuscript (AAM) of an article published by Elsevier in International Business Review. Please cite the published article:}

Kurt, Yusuf and Mustafa Kurt (2020) "Social network analysis in international business research: An assessment of the current state of play and future research directions" International Business Review https://doi.org/10.1016/j.ibusrev.2019.101633

\section{Abstract}

- The theory of networks has attracted increasing attention in international business (IB) research. However, despite its growing theoretical utilization, the systematic description, modelling and analysis of network relationships has been scarce in IB. The field has taken a stand in favour of conventional methodological approaches, which hinders the close interaction between theoretical development and empirical reality in network-based IB research. This study seeks to contribute to this body research by incorporating social network analysis (SNA) as an innovative and promising research tool and aims to shed light on the richness of SNA in fostering IB research, through adding more nuanced network understanding. In particular, it calls attention to its potential applications through exemplifying around two fundamental IB phenomena: firm internationalization and multinational enterprises (MNEs). It concludes by suggesting future directions for utilising SNA in the IB field.

\section{Key Words}

- Social network analysis; business networks; internationalization; multinational enterprises; network structure; structural holes; network closure

\section{Acknowledgements}

- We gratefully acknowledge the comments and recommendations received from $\mathrm{S}$. Tamer Cavusgil, Rudolf R. Sinkovics, Mo Yamin, and Steven Yen-Hung Liu at the different stages of article development. We also thank the IBR editor and two anonymous reviewers. 


\title{
Social network analysis in international business research: An assessment of the current state of play and future research directions
}

\begin{abstract}
The theory of networks has attracted increasing attention in international business (IB) research. However, despite its growing theoretical utilization, the systematic description, modelling and analysis of network relationships has been scarce in IB. The field has taken a stand in favour of conventional methodological approaches, which hinders the close interaction between theoretical development and empirical reality in network-based IB research. This study seeks to contribute to IB research by incorporating social network analysis (SNA) as an innovative and promising research tool and aims to shed light on the richness of SNA in fostering IB research, through adding more nuanced network understanding. In particular, it calls attention to its potential applications through exemplifying around two fundamental IB phenomena: firm internationalization and multinational enterprises (MNEs). It concludes by suggesting future directions for utilising SNA in the IB field.
\end{abstract}

Keywords: Social network analysis; business networks; internationalization; multinational enterprises; network structure; structural holes; network closure. 


\section{Introduction}

Parkhe, Wasserman, and Ralston (2006, p. 560) note that 'networks are reshaping the global business architecture', an idea that is also applicable to current international business (IB) research. The network view has reshaped conventional theoretical understandings by elevating research focus, from being firm-centric towards a more relational, contextual and systemic level (cf. Forsgren and Johanson, 2014). Network thinking has been intensively integrated into various IB phenomena, including internationalization (Coviello, 2006; Johanson and Vahlne, 2009; Yamin and Kurt, 2018), multinational enterprises (Buckley, 2011; Dhanaraj, 2007; Ghoshal and Bartlett, 1990), and foreign direct investment (Chen and Chen, 1998; Jean, Tan, and Sinkovics, 2011), to name a few.

However, despite its growing theoretical utilization, the systematic and empiric analysis of networks has been scarce in IB (Yamin and Kurt, 2018). The field conceptualizes markets as systems of networks and acknowledges that international business activities take place within the context of network relationships (e.g. Forsgren and Johanson, 2014; Johanson and Vahlne, 2009, 2011). Nonetheless, the network view in IB research has been predominantly generic and metaphorical, as structural and positional attributes of networks have not been effectively integrated into empirical analyses. For instance, networks are mostly considered as general webs of relationships, in which network outcomes are assumed to be evenly distributed among the members. However, the structural attributes and configuration of a network in which a focal actor is embedded define the level and type of network outcomes available to the actor. Hence, this approach implies a static network view that treats actors as passive agents and overlooks their conscious and deliberate actions in attempting to create network configurations that benefit them (Ahuja, Soda, and Zaheer, 2012). 
Furthermore, despite the field's increasing recognition of the importance of context in determining opportunities for or constraints on actors (e.g. Michailova, 2011), the influence of structural patterns of social context on actor-level outcomes has not been sufficiently established. This is mainly because context has been treated as homogenous and focus has been largely on actors rather than the patterns of interaction and interdependence among them. Hence, the field's efforts at understanding contexts are likely to be incomplete and potentially flawed without appreciation of the underlying structural patterns of social context (Ahuja, et al., 2012, p. 434). Therefore, for IB scholarship to progress, analytical tools are needed in the analysis of network regularities within social structures, revealing the interdependence of IB activities and actor behaviours and thus developing a more nuanced understanding of networks. This need was identified by IB scholars, who pointed out that 'social networks need to be investigated with appropriate methodologies' (Zucchella, Palamara, and Denicolai, 2007, p. 277).

One such methodology is social network analysis (SNA), which refers to a set of analytical tools for mapping and measuring relationships among social entities, such as individuals, organizations or any social units (Cross, Parker, and Sasson, 2003; Wasserman and Faust, 1994). SNA's essential premise is that the social world and actors within it are created and shaped primarily by relationships and patterns formed by these relationships (Marin and Wellman, 2011). Hence, it takes a fundamentally different perspective from individualist and attribute-based methodologies in explaining actor behaviours and substantive outcomes. It sees the social world in terms of interactions, rather than in an aggregation of actors who act independently, and thus focuses on patterns of relationships as the unit of analysis (Marin and Wellman, 2011).

From an SNA perspective, a notable shortcoming of network-based IB research is its effort to understand actor behaviours and substantive outcomes by employing conventional 
individualist methods, which hinders the compatibility of theoretical development with empirical reality. This incompatibility is primarily associated with the underlying assumption of the independence of conventional statistical methods, which explain the attributes of an entity as a function of other attributes of that same entity (Borgatti and Li, 2009). While IB research theoretically recognizes that causation is located not only in individual attributes, but also in networks within the social context (i.e. Forsgren and Johanson, 2014; Holm, Eriksson, and Johanson, 1996), empirical research is not supported by appropriate methodological tools that can reveal a network's attributes within the social context.

In response to this shortcoming, the purpose of the present study is to propose SNA to IB scholarship as a promising tool for systematically describing, modelling and analysing network relationships. The key contribution of the study lies in demonstrating the rich potential of SNA in revealing the interdependence of actor behaviours and IB activities within network relationships. By suggesting a shift from an actor-centric to a relational focus in the unit of analysis, the study presents how the use of SNA can lead to more nuanced understandings of existing network-based theoretical frameworks and organizational conceptualizations.

The study is not primarily engaging in a technical analysis of network data, as there are seminal sources (e.g. Borgatti, Everett, and Johnson, 2013; Wasserman and Faust, 1994) that can guide IB scholars in SNA's methodological application. Rather, it aims to draw the attention of IB scholars to the untapped potential of SNA by exemplifying around two fundamental IB phenomena: firm internationalization and multinational enterprises (MNEs). The utilization of SNA in network-based IB research is far from exhausted. Hence, this is a timely and important attempt, as building bridges with other disciplines and close integration between theoretical development and empirical reality with appropriate analytical tools are considered to be exactly 
what IB research needs to proceed as a viable and progressive field (Buckley, Doh, and Benischke, 2017; Cheng, Henisz, Roth, and Swaminathan, 2009).

The remainder of the paper is structured as follows. The next section introduces SNA with its key concepts. It is followed by an extensive review of the IB literature to demonstrate how and how far SNA has been utilized so far. The subsequent section develops the core arguments around two fundamental IB domains in which SNA can advance our existing understanding. The paper concludes with suggestions for future research directions in utilizing SNA.

\section{Social network analysis}

\subsection{What is social network analysis?}

A social network is defined as a finite set or sets of actors (e.g. people, organizations or other social entities) and the relation or relations defined on them (Wasserman and Faust, 1994, p. 20). Social networks play a fundamental role as a means of spreading information, ideas, resources, and influence among members (Kempe, Kleinberg, and Tardos, 2003; Lea, Yu, Maguluru, and Nichols, 2006). The basic assumptions at the heart of social network research include: that exchange is embedded in social relations and complex social structures; that relationships do not occur in isolation; and that relationships matter in terms of outcomes at both actor and group levels (Kilduff and Brass, 2010).

SNA focuses on the analysis of relationships among social entities, and on the patterns and implications of these relationships (Wasserman and Faust, 1994). It is not a formal theory, but rather a set of analytical tools for investigating social structures (Marin and Wellman, 2011;

Otte and Rousseau, 2002). Based on the mathematical approaches of graph theory, it enables relationships to be represented and described systematically and compactly (Hanneman and Riddle, 2005; Scott, 2013). Where traditional social science methods have mainly relied on 
'attribute data' concerning the properties of particular actors, SNA deals with 'relational data', dealing mainly with the properties of network relationships among actors (Scott, 2013).

In contrast to traditional individualist methodological approaches that focus on actors as the unit of analysis, SNA takes relationships among actors as the unit of analysis and asserts that actors' behaviours are influenced by the structural regularities of relationships surrounding them (Borgatti and Li, 2009; Carter, Ellram, and Tate, 2007; Otte and Rousseau, 2002). Based on Coleman (1958) earlier discussions, Fombrun (1982, p. 281) emphasized the distinction between traditional methodologies and SNA:

In usual statistical analysis, [an] interview is regarded as independent of others... [whereas in network analysis] an individual is seen as a part of some larger structure in which the respondent finds himself...Thus, the individual is not treated independently. He is seen embedded in a context that both constrains and liberates.

Thus, SNA offers the possibility of leveraging social and behavioural science research through providing precise formal definitions of, and metrics for, aspects of the social context in which actors are embedded (Wasserman and Faust, 1994, p. 3). In their seminal work, Wasserman and Faust (1994, p. 4) identified four central principles of SNA that distinguish it from other research approaches: (i) actors and their actions are considered to be interdependent rather than independent; (ii) relationships between actors are seen as channels for tangible and intangible resources; (iii) network patterns either facilitate or constrain individual actions; and (iv) social structures are conceptualized as patterns of relations among social actors. In sum, the relationships between actors, the properties of relationships and their influence on actors' behaviour are among the prime concerns and the unit of analysis in SNA. Hence, SNA offers

\footnotetext{
${ }^{1}$ Attributes and relational data are not the only types of data in social sciences: a third type of data is ideational data, which directly describes the meanings, motives, definitions and typifications involved in actions (Scott, 2013, p.3).
} 
analytical tools distinct from the traditional methods of statistics and data analysis (Wasserman and Faust, 1994).

\subsection{Key concepts in social network analysis}

This section introduces some of the key SNA concepts (i.e. open and closed networks, actor centrality, and core and periphery structure), as core arguments in subsequent sections are developed with reference to these SNA metrics. The concepts are mainly discussed with reference to the concept of social capital, which is defined as 'the sum of the actual and potential resources embedded within, available through and derived from the network of relationships possessed by an individual or social unit' (Nahapiet and Ghoshal, 1998, p. 243).

\section{Open network (structural holes)}

An open network can be understood as a network structure in which structural holes exist. Structural holes refer to links between otherwise disconnected groups (Burt, 1992, 2000). The core proposition of structural holes is that network positions associated with the highest social capital lie between rather than within dense regions of relationships (Walker, Kogut, and Shan, 1997, p. 112). The key benefit of open networks results from accessing complementary, novel, and heterogeneous knowledge and resources (Reagans and McEvily, 2003). Additionally, firms in open networks possess higher independence and greater latitude in their cooperative strategies (Walker, et al., 1997). The IB literature has touched upon the concept of structural holes in explaining the identification and exploitation of international business opportunities. For example, international entrepreneurship is explained as a function of brokerage opportunities relating to the position of structural holes (Ellis, 2011). 


\section{Closed network (network closure)}

Network closure refers to a network structure in which all actors are connected directly or through third parties (Burt, 2001). This highlights the impact of cohesive networks on the creation of social capital. The two fundamental outcomes of closed networks - more specifically, networks of densely interconnected contacts - are access to information and facilitating sanctions that make it less risky for people in the network to trust one another (Burt, 2001, p. 37; Coleman, 1988). The presence of common third parties facilitates trust and creates incentives to cooperate, deriving from concern for one's reputation and fear of group sanctions (Gargiulo, Ertug, and Galunic, 2009). While network closure provides benefits in terms of social capital, it also increases information redundancy, as cohesive and structurally equivalent contacts are likely to have similar information (Burt, 1992, 2001; Gargiulo, et al., 2009). Additionally, a closed network is likely to reduce actor autonomy in cooperative strategies with outsiders because of the potential sanctions and expectations of others in the network (Gargiulo, et al., 2009).

\section{Centrality}

Centrality is a property of a node's position in a network (Borgatti, et al., 2013). As a metric measuring actor positioning, centrality metrics are widely applied as indices of the power, prestige, influence, prominence and importance ${ }^{2}$ of nodes within a network (Brass, 1984; Sparrowe, Liden, Wayne, and Kraimer, 2001). Centrality is mainly associated with instrumental outcomes, such as an individual's access to network resources and social capital. Central actors have more relationships through which to obtain resources and also are less dependent on any one single actor (Sparrowe, et al., 2001). Centrality also provides an advantage in terms of the degree of control an actor might exert over the relationships and flow/exchange of resources. SNA offers

\footnotetext{
2 The basic assumption here is that an actor is important if the ties of that actor make the actor visible to other actors in the network (Wasserman and Faust, 1994: 172).
} 
various centrality measures for the identification of the most important actor(s) in a social network, including degree centrality, closeness centrality, betweenness centrality and eigenvector centrality (see Borgatti, et al., 2013)

\section{Core and periphery structure}

Core and periphery structure is 'characterized by a cohesive subgroup of core actors and a set of peripheral actors that are loosely connected to the core' (Borgatti and Everett, 2000; Cattani and Ferriani, 2008, p. 826). Actors located in the core or periphery are subject to different sets of opportunities and constraints. While the core nodes enjoy the flow of tacit knowledge in dense, close-knit networks in which they are embedded, the peripheral nodes have the advantage of connections outside the network that facilitate novel information flows (Cattani and Ferriani, 2008). Table 1 illustrates the SNA measures explained above.

Insert Table 1 around here

\section{Applications of SNA in international business research}

In order to determine the status quo of SNA in international business research, an extensive literature review was conducted in leading IB journals, following the study of Tüselmann, Sinkovics, and Pishchulov (2016), which provided a recent ranking of IB journals. Although this does not cover the complete set of possible outlets publishing IB-related research, we believe that the selected journals are a representative of the research trends in terms of both the phenomenon of interest and the field in general. The journals included in the review are presented in Table 2. 


\section{Insert Table 2 around here}

The literature review, conducted through key academic publishing databases (i.e. ABI/Inform, Elsevier ScienceDirect, Emerald Insight, and Google Scholar), revealed 20 academic articles that applied SNA in the IB field. The website of each journal was also searched for articles employing SNA. The review assessed the main motivation for the application of SNA, the type of network data used, and the software employed for social network analysis. Table 3 lists all the identified articles that use SNA in IB journals.

\section{Insert Table 3 around here}

The review provides evidence of limited yet increasing utilization of SNA in IB research, particularly in recent years, and shows that authors' key motivation for using SNA was its ability to generate empirical insights into structural and relational patterns among social actors. Applying SNA leads to a better representation of the interdependence of actors and hence deeper understanding of their behaviours within different network structures. The studies generally used SNA measures such as network density, network range, degree, closeness, and betweenness centrality. Through employing SNA, these articles aimed to develop existing understandings of various IB topics, including knowledge/information flows, talent management, firm internationalization, corporate social responsibility and organizational learning. The studies largely used UCINET as analysis software, but other software packages (i.e. Gephi, Pajek, Bibexcel) were also employed to reveal the structural and positional attributes of networks and 
actors. The key data sources for these studies are both quantitative primary data collected through social network surveys, and secondary archival, co-citation and patent data. The next section develops ideas of potential IB topics in which SNA can advance existing understanding.

\section{Potential avenues for the application of SNA in the IB field}

Although SNA can be applied to virtually any sub-domain of the IB field, the objective here is to delineate the potential of SNA by showing how and how far it can advance existing knowledge. Drawing upon recent discussions of IB scholars in tackling 'big questions' (Buckley, 2002; Buckley, et al., 2017; Buckley and Ghauri, 2004; Peng, 2004), we identified two major areas that have propelled the development of IB as a research field: namely, the internationalization of firms and the MNE phenomenon. The rationale of focusing on these topics is twofold. First, understanding the internationalization of firms has been a core pillar of IB research and central to multiple theoretical approaches, including new international ventures and born-global frameworks, the regionalization theory, and the process model (Riviere and Bass, 2018). Second is the pre-eminence of the MNE as the global organization of interest within the IB field (Teegen, Doh, and Vachani, 2004). MNEs are regarded as dominant actors in international business activities and an ideal context for the development of IB theories (Roth and Kostova, 2003; Rugman and Brain, 2003). Furthermore, through the inclusion of network thinking, these two research bodies have witnessed a tremendous evolution in advancing both traditional theoretical models and organizational conceptualizations, such as the revised Uppsala internationalization model (Johanson and Vahlne, 2009) and the global factory (Buckley and Ghauri, 2004). Hence, these two central tenets of IB research serve as ideal contexts to demonstrate the rich potential of SNA for IB research. 


\subsection{Revisiting internationalization research with SNA perspective}

\subsubsection{Internationalization and network theory}

Internationalization has been one of the main research streams in IB (Buckley, 2002).

Internationalization research, particularly studies focusing on small and medium-sized enterprises (SMEs), born-globals and international new ventures, has extensively employed a network perspective (Cavusgil and Knight, 2009, 2015; Coviello, 2006; Hånell and Ghauri, 2016; Kontinen and Ojala, 2011; Odlin and Benson-Rea, 2017; Sinkovics, Kurt, and Sinkovics, 2018). Although this body of the literature recognizes networks as effective means of accessing external resources, the fact that networks vary in terms of the extent to which they provide accessible resources has been mostly overlooked. In other words, previous network-based internationalization research has applied a static and generic network view and thus left considerable variance between different network configurations and their subsequent network outcomes unexplained.

While several theories have been developed to explain the internationalization of firms, Johanson and Vahlne's (1977) Uppsala model has been one of the most influential in explaining the process of firms' gradual commitment to foreign markets. The model introduced the liability of foreignness as the key impediment to internationalization and discussed the process through which firms gradually increase their market knowledge and market commitment. This model has received criticism for being deterministic and firm-centric, but later conceptualizations have incorporated a network perspective in explaining the internationalization (Johanson and Vahlne, 1990, 2006, 2009; Vahlne and Johanson, 2013). The most dramatic shift was introduced in the 2009 revised model, in which the concept of the liability of foreignness was replaced with the liability of outsidership (Johanson and Vahlne, 2009; Yamin and Kurt, 2018). The revised model viewed markets as webs of network relationships and asserted that firms internationalize within 
networks of connected business relationships (Johanson and Vahlne, 2009). This model was a full-blown application of network theory to internationalization research (Yamin and Kurt, 2018).

The revised model created room for new research, which probed the 'network' component of the phenomenon more deeply, through employing the theoretical apparatus of SNA. In one of these studies, Yamin and Kurt (2018) employed the SNA-related structural and positional attributes of networks to theorize the relationship between the liabilities of foreignness and outsidership. The paper argued that the structural characteristics of the target network affect the motivations of both insider and outsider actors, in terms of overcoming the liability of outsidership. Moreover, the perceived liability of foreignness of the outsider determines whether the outsider should build its insidership within a closed or open network, considering the different benefits of both in facilitating tacit knowledge-sharing as opposed to explicit information flows (Kurt and Yamin, 2016; Yamin and Kurt, 2018). The recent studies utilizing SNA-related concepts also shed light on the potential empirical application of SNA to internationalization research.

\subsubsection{Internationalization and SNA}

Internationalization research has relied extensively on attribute data and traditional methodological perspectives, which concern the focal actor explaining its internationalization in terms of notions such as firm resources, managerial capabilities and international experience. Data was primarily collected through surveys and interviews and analysed with traditional statistical tools. The utilization of relational data in revealing the role of social structure in influencing firm internationalization has been rare, with few exceptions (i.e. Coviello, 2006).

Through integrating relational data, SNA can contribute to this body of IB research in various ways. Firstly, whereas Johanson and Vahlne (2009) argued that building insidership is a 
necessary condition for successful internationalization, they did not explicitly specify how and how far the characteristics of the target network in which the outsider builds an insidership position can facilitate/impede or expedite/decelerate the internationalization process (Yamin and Kurt, 2018). They indicated that 'anything that happens, happens within the context of a relationship, and a firm that is well established in a relevant network or networks is an "insider"” (Johanson and Vahlne, 2009, p. 1415). They employed a generic network view and did not clearly articulate what 'well established' means in the network context. Different perspectives have also emerged from disagreements over what 'better connected' means (Yamin and Kurt, 2018). The social network literature provides two fundamental competing views regarding the 'well established' (i.e. better-connected) dichotomy. Building on the concept of social capital, Coleman (1988) argues that actors are better connected in dense networks, whereas advocates of open networks argue that firms occupying the structural holes position are better connected and more well-established (Burt, 2001). In other words, while network closure argues that social capital is created in densely-connected networks (Coleman, 1988), the structural holes perspective argues that social capital is an outcome of the brokerage role between otherwise disconnected groups (Burt, 2000).

SNA can enable identification of the most valuable 'well established' status for an internationalizing firm in a target network that provides the required social capital for entering the market. For instance, building an insidership position in an open network for entering a psychically close market might be a viable strategy, as the cost of building relationships in an open network is likely to be relatively low. Further, the information benefits of an open network in this context would be sufficient, considering the low level of the liability of foreignness and psychic distance between home and host markets (Yamin and Kurt, 2018). On the other hand, a firm seeking to enter a psychically distant market would benefit more from building an 
insidership position in a dense network structure, which can provide social network benefits to overcome high liability of foreignness. However, the cost of building insidership in a dense network is likely to be higher.

Secondly, building insidership is a two-sided process and both insider and outsider should be motivated to overcome (or help to overcome) the outsidership. The motivational disposition of the insider in helping the outsider is bounded by the network structure in which the insider is embedded. Actors in open networks are likely to have more flexibility in opening doors for outsiders, while actors in closed networks are likely to be restricted by dense network structures, as adding a new actor eventually affects all relationships in a closed network (Yamin and Kurt, 2018). Therefore, SNA can reveal the structure of the foreign market network, in which the optimal insider actor can be targeted to build the most effective insidership position.

Third, the positional features of the insider actor through which the outsider wishes to build insidership also affect the internationalization process. SNA enables identification of the key actors who can provide the necessary resources required to internationalize successfully. For instance, linking to a central actor in the target network can provide reputation capital, legitimacy and acceptance in the target market. Yet, it demands the investment of more resources and time to convince the insider. On the other hand, building insidership through a peripheral actor is likely to be faster and less costly. If an internationalizing firm needs only basic market information, then it would be more feasible to connect to a peripheral actor for market entry. A firm's choice of whether a central or peripheral actor would be more beneficial is shaped by their perceived liability of foreignness in the target market and the costs of building insidership. 


\subsubsection{SNA and overcoming the liability of outsidership: An illustrative example}

To give a visual representation of the role of network structure and actor positioning in accessing different forms of social capital required for internationalization, a hypothetical network scenario case, in which node 15 seeks to enter a host country through building an insider position in the target network, is provided below (Figure 1).

Figure 1 around here

Starting with the home country network, previous network studies investigating the role of home country networks in firm internationalization implicitly assume that all actors embedded in a home country network are able to access the same network resources and social capital. However, the structure of networks surrounding the focal actors and the actors' position within the network affect the type and level of social capital and resources available. For instance, whereas node 15 enjoys the benefits and social capital created in its surrounding dense network and high central position, node 22 does not have access to the same level and type of social capital, due to its peripheral position in an open network (Burt, 2001; Coleman, 1988). Similarly, node 18 lacks the social capital created in the dense network, while its structural holes position enable it to access novel information from otherwise disconnected sub-groups (Burt, 2001).

Secondly, regarding overcoming the liability of outsidership and host country networks, the structural attributes of the target network and the position of the insider within it are not a 
feature of Johanson and Vahlne's (2009) insidership analysis. Their theory argues that insidership is built within target host country networks displaying trust and commitment, reflecting a dense network structure, which entails trust and commitment, in the host country. However, as indicated by Yamin and Kurt (2018, p. 3), 'not all networks are the same nor [do] all network relationships necessarily engender trust and commitment or to the same extent'. For instance, open networks have relatively low levels of relational trust compared to closed networks. Based on Johanson and Vahlne's (2009) insidership perspective, one would expect no difference, if node 15 , as an internationalizing firm, is connected to either node 1 or node 8 within the target network of the host country. However, from the SNA perspective, building an insidership position via connecting to node 1 provides benefits in terms of social capital produced in dense networks (i.e. trust, relational norms, and sensitive/tacit knowledge). On the other hand, building insidership in the same target network of the host country via node 8 cannot provide the same type and level of social capital. Node 8 can only provide social capital created in open networks, such as flows of non-redundant and novel information.

On the other hand, the cost of building insidership via node 1 is likely to be higher than an insidership position built via node 8 , as insidership in closed networks requires more resources and time than open networks. Decisions on whether a firm should build insidership in open or closed networks in a host country depend on an analysis of the cost of insidership and the type of social capital needed for successful internationalization. For instance, building insidership in an open network for entering a psychically close market might be a viable strategy, for two reasons. First, the cost of building relationships in an open network is likely to be lower than that of a closed network. Moreover, the information and resources acquired via an open network would be sufficient for internationalization, considering the low risk of foreignness and psychic distance (Kurt and Yamin, 2016; Yamin and Kurt, 2018). Therefore, building insidership via node 8 
would be a more viable strategy for the internationalization of node 15 if the host country is psychically close. On the contrary, internationalization to psychically distant markets requires insidership in closed network structures, as the firm needs tacit and sensitive knowledge that can be obtained via trust-based closed networks. The internationalizing firm is likely to invest in building insidership in closed networks only if the expected benefits exceed the cost. Expected benefits of social capital created in dense networks would be valued more highly if the firm has high liability of foreignness in relation to the host country. Therefore, building insidership via node 1 would be a viable strategy for the internationalization of node 15 if the host country is psychically distant.

In sum, a deeper and more nuanced understanding of overcoming the liability of outsidership requires paying closer attention to the structural characteristics of networks in which internationalization takes place. Internationalization cannot be fully explained by the individual attributes of internationalizing firms alone. It requires a broader perspective that considers the attributes of networks and actor interdependence within the social structures in which internationalizing firms are embedded, rather than seeing networks as similar entities. SNA can be used as a significant methodological tool that reveals structural and positional attributes of networks of both home and host countries, across which internationalization occurs. Hence, IB scholars and managers of internationalizing firms could gain a richer understanding of overcoming the liability of outsidership in networks.

\subsection{Reconsidering multinational enterprises through the lens of social network analysis}

The research on the existence, organization and strategy of MNEs is a fundamental pillar of the IB field (Buckley, 2002; Peng, 2004). Further, IB scholars agree that the distinctive 
characteristics of the MNE context (i.e. heterogeneity, complexity) hold promise in terms of enriching existing theoretical models or developing new IB theories (Roth and Kostova, 2003). However, as indicated by Roth and Kostova (2003, p. 894), this promise can only be fully realised through more rigorous and systematic approaches. Similarly, Dhanaraj (2007, p. 1233), in his review of the book by Forsgren, Holm, and Johanson (2005), suggested the use of recent advances in network analysis for developing more nuanced understandings of the network structures of multinationals. In this respect, SNA may reveal the complex intra- and interorganizational network structures of today's MNEs in their heterogeneous and complex social contexts. In turn, MNE behaviours, strategies, performance outcomes, and their interdependence with social/network contexts could be better understood. In a similar vein, this study suggests the use of SNA to complement the theoretical developments in the network conceptualization of MNE with appropriate analysis of the empirical reality. The following sections discuss how this body of research provides an ideal context for the utilization of SNA, which can then contribute to a more nuanced understanding of networked-MNEs.

\subsubsection{MNEs as networked organizations}

Early IB research and theories aimed to understand the existence of MNEs (Buckley and Casson, 1976; Coase, 1937; Dunning, 1988; Hennart, 1982; Penrose, 1959). Where earlier studies considered multinationals as closed systems vis-à-vis markets, later conceptualizations incorporated a relational approach and extended the boundaries of MNEs into markets seen as webs of network relationships (Buckley, 2009b; Forsgren, et al., 2005; Ghoshal and Bartlett, 1990). As indicated by Cantwell, Dunning, and Lundan (2010, p. 569), an MNE is now understood 'as a coordinated system or network of cross-border value-creating activities, some of which are carried out within the hierarchy of the firm, and some of which are carried out through 
informal social ties or contractual relationships'. Similarly, Forsgren, et al. (2005) argue that understanding MNEs requires consideration of their embeddedness in business networks in order to generate more complete findings. The analysis carried out by Forsgren, et al. (2005) revealed the importance of business networks in understanding MNEs as networked organizations. As today's MNEs are becoming a system of differentiated networks, Buckley and Ghauri (2004) concept of 'the global factory' serves as the most appropriate and fruitful conceptualization of MNEs for the integration of SNA into the MNE research context. Hence, the arguments in this section will be developed with reference to the global factory.

\subsubsection{Global factory as a networked MNE}

Buckley and Ghauri (2004) introduced the concept of 'the global factory' as a new structure for an MNE. From a Coasean 'externalise or internalise' point of view, the global factory reflects the externalization of activities through outsourcing (Buckley, 2009a). This emphasizes the role of the centre (HQ) as the orchestrator of complex and extensive networks of organizations, within or beyond the legal boundaries of the focal firm (Buckley, 2009a, 2011; Buckley and Ghauri, 2004; Yamin, 2011). The global factory model depicts a complex web of relationships among brand owners, contractors and suppliers, which together denote different levels of activities (i.e. design, R\&D, manufacturing, distribution) under the control of the brand owner. Buckley's (2009b) original discussion emphasizes the importance of the structural attributes of the network in affecting the benefit/cost outcomes of those networks:

Global factories are both horizontal and vertical networks... The benefits of the horizontal network arise from learning and the diffusion of knowledge. The benefits of the vertical network arise from the coordination of activities...The degree to which benefits outweigh costs depends on the extent to which the global factory's networks are open and transparent versus being closed and opaque. (Buckley, 2009b, pp. 229-230) 
As Buckley indicates above, the structural attributes of networks (i.e. open versus closed) determine the outcomes of horizontal and vertical networks (i.e. learning, co-ordination) that constitute the global factory. Buckley's conceptualization of the global factory is also related to the 'better connected' dichotomy in terms of whether open or closed networks are more beneficial for the lead firm in orchestrating activities. Different enabling features of network structures, such as facilitating the transfer of tacit knowledge in closed networks versus the flow of novel information in open networks, can provide different benefits for the lead firm. On the other hand, the costs of building and sustaining relationships in open or closed networks are different. Therefore, firms' decisions on developing networks in open or closed networks can be understood as a result of their cost-benefit analysis.

For instance, developing closed networks around core functions (i.e. design, engineering and $R \& D)$ can facilitate the flow of tacit knowledge among tightly-connected units. Closed networks foster learning through increasing trust and the willingness of units to try to transfer knowledge, curbing opportunism and creating cooperative norms via third-party ties (Cavusgil, Calantone, and Zhao, 2003; Reagans and McEvily, 2003). However, developing and sustaining dense networks comes with two fundamental costs. One is the high investment in terms of time and resource required for forming and sustaining networks with network partners; and the other relates to the 'paradox of embeddedness' (Uzzi, 1997). Actors embedded in dense networks may lack access to novel and non-redundant information that exists beyond their network (Fritsch and Kauffeld-Monz, 2008), which can impede their performance.

Conceptualization of the global factory as a networked organization consisting of vertical and horizontal networks provides a rich context in the utilization of SNA. For instance, executing an appropriate cost-benefit analysis of different network structures, as suggested by Buckley (2011), requires one to reveal and clearly visualize open and closed network structures. The 
optimum network structure based on cost-benefit analysis, which provides competitive advantages, can be achieved via effective network management through applying SNA.

\subsubsection{Coordination and control in the global factory and SNA}

A recent relevant discussion of the global factory revolved around who controls dispersed activities and captures the rents earned in global value chains (GVCs) (Buckley and Strange, 2015). The positions of the actors (either lead firm or suppliers) and the structure of the network in which value chain activities are carried out affect the distribution of power and rent in GVCs. Forsgren, et al. (2005) note that MNE subsidiary power comes not only from unique resources, but also from unique network position. For instance, external embeddedness of the subsidiary, through which it can access heterogeneous resources via its 'structural holes' position, contributes its power within the MNE. Regarding power relationships within the global factory, Buckley (2011, p. 280) indicated that:

The position of the MNE's headquarters in the global factory is important to its power...power is a function of centrality. The more physical and knowledge links that the headquarters possesses in the global factory, the more it might be argued to have power over the global network.

Thus, we need to borrow credible measures from SNA (i.e. centrality) to reveal the positional attributes of the actors and understand the power dynamics within the network structure of the global factory. Centrality has been amongst the most fundamental concepts in SNA and is highly associated with power (Borgatti, 2005). Central actors are those tied to a greater number of other actors than those who are peripheral actors (Mizruchi and Potts, 1998). Power is function of an actor's ability to monopolize the dependence of other actors, which is derived from its structural position in its surrounding networks (Cook, Emerson, Gillmore, and Yamagishi, 1983; Mizruchi and Potts, 1998). In the global factory, the assumption is that the lead 
firm has the ability to monopolize the dependence of contractors, suppliers and other actors. However, the power of the lead firm in the value chain activities can be better understood through revealing its position within the network structure. Hence, SNA offers numerous measures, including degree centrality, closeness, betweenness and eigenvector centrality (Borgatti, 2005), which can reveal whether the focal actor's position generates any power and control benefits.

Furthermore, Buckley (2011) also highlighted the need and value of employing SNA metrics in understanding coordination of the global factory. Success in the global factory is considered to be dependent on the effective orchestration and coordination of activities across both ownership and non-ownership ties of globally interconnected units. Following Ghoshal and Bartlett (1990), Buckley (2011, p. 280) further argued that the performance of the global factory is dependent upon '(1) the density and (2) the cohesiveness of (a) the internal networks and (b) the external networks of global factories'. Therefore, understanding the antecedents of the performance of 'the global factory' as well as the 'embedded multinational' requires credible SNA measures, such as density, coherence, and other metrics measuring network structures. Both the internal networks of the global factory and its embeddedness within the external networks affect its performance. Managing this complexity in networks requires appropriate analytical tools to map the relationships. Hence, empirical application of SNA can hence develop a more nuanced understanding of the structure, organization and performance of today's networked multinational organizations.

\subsubsection{An overview of SNA's potential utilization in the context of MNE research}

Based on the above arguments positing the importance of network relationships in the organization and strategy of the global factory, SNA can further contribute to the MNE research context in various ways. Firstly, unlike earlier studies that conceptualized multinationals as 
closed systems vis-à-vis markets, the relevant contemporary literature agrees that MNEs are networked organizations. In particular, the concept of the global factory reflects an absolute network understanding of MNEs. The success, governance and control of the global factory are associated with its capability to orchestrate a complex web of networks of globally interconnected units. However, current studies only benefit theoretically from the notion of a network to understand the global factory. Hence, empirical utilization of SNA can enable scholars and practitioners to reveal and understand the network structure of globally interconnected value chain activities organized by HQs, through which control, governance, rent capturing and performance dimensions can be appropriately understood.

Secondly, Rugman and Verbeke (2004) introduced a dichotomy between 'regional MNE' and 'global MNE' through focusing mainly on downstream sales of MNEs. Despite a common perception that multinationals pursue global strategies, their study showed that most of the world's largest companies are not global, but regional. They indicated that a strong discrepancy between intra-regional and inter-regional sales is likely to have important implications for MNE structure (Rugman and Verbeke, 2004, p. 14). Regional MNEs are treated as complex, differentiated organizational systems vis-à-vis global MNEs. The success of regional MNEs is associated with their ability to overcome the 'regional effect', which is conceptualized as a liability of outsidership imposed on subsidiaries operating in the host region (Verbeke, Kano, and Yuan, 2016). In other words, building insidership in the host region via subsidiaries and hence exploiting location-bound, firm-specific advantages (FSAs) are key critical success factors for regional MNEs. This requires clear empirical evidence of the network structure of host regions in which optimal 'insidership' positions can be developed by considering the distinctive enabling characteristics of different network structures and actor positions. In this respect, SNA can enable us to visualise network structures in host regions, through which imperfections across national 
and regional factor markets can be optimally exploited, and production and coordination costs reduced (ibid.). Similarly, SNA can help us to better understand the well-known Bartlett and Ghoshal (1989) matrix through empirically substantiating the structural differences between transnational, global and multi-domestic MNEs.

\section{Discussion and suggestions for future research}

Recent studies have criticised the state of the IB field and recommended ways in which IB research can progress (Buckley, et al., 2017; Buckley and Lessard, 2005; Delios, 2017). The key criticism has been the 'inward-looking' approaches of IB scholarship, which restricts interdisciplinarity (Buckley, et al., 2017). The success of IB in its early decades was associated with its interdisciplinary roots, which integrated concepts and tools from different disciplines in seeking to answer the 'big questions' (ibid.). Similarly, a recent and important recommendation for advancing IB research is to incorporate interdisciplinary perspectives and use state-of-art methodological approaches to develop innovative research designs that acknowledge interdependencies among social actors in the global environment (Buckley, et al., 2017).

Buckley (2002, p.370) argued that 'these successes were achieved by identifying the key empirical factors in the global economy which needed to be explained and then searching out a tractable means of explication within a coherent theoretical framework'. Today, as markets are seen as a web of networks where actors are interlinked via relational ties, the success of the field very much depends on appropriate efforts to understand actor interdependence within the social

structures where IB activities take place. Hence, IB scholars need to be equipped with appropriate analytical tools to be able to identify key empirical factors.

Moreover, a close relationship between theoretical development and empirical reality has been considered the key strength of past epochs of IB research (Buckley, 2002). However, an 
interdisciplinary perspective and a close interaction between theory and empirical reality have not been yet achieved in network-based IB research. A major impediment has been IB scholars' stand in favour of traditional methodologies and a reluctance to apply state-of-art methodological approaches to network relationships. In this vein, SNA, as an analytical tool borrowed from sociology, has tremendous potential in advancing fundamental understanding, particularly in the IB field, as the notion of networks has been extremely rewarding in answering 'big questions'. In response to aforementioned recommendations for more interdisciplinary IB research through the integration of ideas and methods from different disciplines, this study is a timely attempt to suggest SNA to IB scholars as an analytical research tool. It contributes to the IB field by demonstrating the potential of SNA through articulating its potential application to two tenets of IB: firm internationalization and MNEs. However, the study's implications are applicable to any domain of IB.

Further, SNA's previous successful applications in other disciplines (i.e. supply chain management, economic geography, knowledge management and innovation) can also shed light on its application in multiple sub-domains of IB research. Firstly, SNA offers great potential for supply chain management (SCM) research in investigating how patterns of network relationships translate into competitive advantage through the management of resource flows, diffusion of information, social control of opportunism and coordination, amongst others (Borgatti and Li, 2009). While early SCM research focused on linear relationships between buyers and suppliers, recent studies have benefited from SNA to capture the complexity of the larger supply network in which the firm is embedded (Kim, Choi, Yan, and Dooley, 2011). SNA contributes to the SCM literature through revealing vertical and horizontal network interdependencies between multiple firms participating in a supply chain. Previous studies also pointed out the managerial importance of revealing interdependencies in supply chain network structures by highlighting that firms that 
understand and deliberately reconfigure their supply networks can outperform competitors (Carter, et al., 2007; Choi, Dooley, and Rungtusanatham, 2001). Furthermore, as noted by Lazzarini, Chaddad, and Cook (2001), firms can design effective coordinating mechanisms by considering different interdependencies emerging from strong or weak ties via employing SNA.

Building on existing developments in the integration of SNA into the SCM context, IB scholars can extend this body of research by examining global supply chains in which supply networks and buyer-seller relationships cross borders. Managing global supply chains effectively is a prerequisite for remaining competitive for MNEs. Hence, IB scholars and practitioners can benefit considerably from SNA as a means to analyse the complex and dynamic nature of supply chains and the effect of potential perturbations of supply networks (Wu, Blackhurst, and O'grady, 2007). Revealing global supply chain network structures via SNA may have implications for designing robust supply network configurations against possible supply disruptions (Kim, et al., 2011). Moreover, today's compound political, social and economic uncertainties, emerging from anti-globalization sentiments and protectionist policies (Sinkovics, et al., 2018), are likely to have a serious effect on global connectivity and the sustainability of global supply chain activities. In this vein, SNA might be of profound importance in responding to potential disruptive challenges, through examining supply chain networks and thus analysing resilient supply chain configurations.

Secondly, in economic geography, SNA has been considered a promising tool for empirically investigating the structures and evolution of inter-organization networks and knowledge flows within and across regions (Ter Wal and Boschma, 2009, p. 739). The development of global value chain (GVC) and global production networks (GPN) perspectives in this field has brought valuable insights to the social and political relations between actors involved in the process of value capture in the production of commodities (Cumbers, Nativel, and Routledge, 2008). As 
previously suggested, the GVC/GPN literature can contribute to key debates in IB research, particularly those concerned with networked multinationals (Azmeh and Nadvi, 2014). Therefore, building on SNA's previous successful application in relational economic geography, IB research can also utilize it for analysing complex and geographically dispersed webs of production networks, which IB considers to be orchestrated by leading MNEs. Additionally, in her research incorporating a relational perspective into GVC governance, Kano (2018) argued that orchestrating firms can enhance sustainability and efficiency outcomes in GVCs through using social mechanisms, including network relationships. Accordingly, SNA can foster this understanding through revealing the network structure and interdependencies within the social context in which GVCs are embedded, and thus allow the design of resilient value chain configurations.

Finally, previous research investigating different network contexts needs to be revisited through empirically integrating social network data and analysis into existing knowledge and understanding. For instance, informal constraints constituted within interpersonal networks in emerging markets (i.e. guanxi, blat, and chaebol) are accepted as effective safeguards against opportunism, and facilitate transactions when formal market-supporting institutions are underdeveloped (Peng, Sun, Pinkham, and Chen, 2009). However, social capital benefits such as social norms curbing opportunism, cooperative behaviours and trust can emerge in the context of closed network structures. Therefore, understanding the effectiveness of these social networks in navigating business activities in institutionally weak environment requires systematic analysis of their structural configurations, in which both densely- (closed network) and loosely-connected (open network) regions within the overall network might exist. For example, building an insidership position within a guanxi network might not simply translate into informal constraint benefits if the focal actor builds networks in loosely-connected guanxi structures. SNA can 
empirically reveal structural configurations and attributes of these network systems and their impact on international business activities.

A longitudinal approach can empirically reveal dynamic changes of network structures and actor positions over time and the effect of these changes on international business activities. We hope this study stimulates future research that utilizes SNA in developing more precise and nuanced network understanding in IB research and thus contributes to the progressive development of the field. 


\section{References}

Ahuja, G., Soda, G., \& Zaheer, A. (2012). The Genesis and Dynamics of Organizational Networks. Organization Science, 23, 434-448. doi:10.1287/orsc.1110.0695

Awate, S., Larsen, M. M., \& Mudambi, R. (2012). EMNE catch - up strategies in the wind turbine industry: Is there a trade - off between output and innovation capabilities? Global Strategy Journal, 2, 205-223. doi:10.1111/j.2042-5805.2012.01034.x

Azmeh, S., \& Nadvi, K. (2014). Asian firms and the restructuring of global value chains. International Business Review, 23, 708-717. doi:10.1016/j.ibusrev.2014.03.007

Bartlett, C. A., \& Ghoshal, S. (1989). Managing across borders: The transnational solution: Harvard Business Press.

Bolívar, L. M., Casanueva, C., \& Castro, I. (2019). Global Foreign Direct Investment: A network perspective. International Business Review, 28, 696-712. doi:10.1016/j.ibusrev.2019.01.007

Borgatti, S. P. (2005). Centrality and network flow. Social Networks, 27, 55-71. doi:10.1016/j.socnet.2004.11.008

Borgatti, S. P., \& Everett, M. G. (2000). Models of core/periphery structures. Social Networks, 21, 375-395. doi:10.1016/S0378-8733(99)00019-2

Borgatti, S. P., Everett, M. G., \& Johnson, J. C. (2013). Analyzing social networks. Thousands Oak, CA: Sage.

Borgatti, S. P., \& Li, X. U. N. (2009). On Social Network Analysis in a Supply Chain Context. Journal of Supply Chain Management, 45, 5-22. doi:10.1111/j.1745-493X.2009.03166.x

Brass, D. J. (1984). Being in the Right Place: A Structural Analysis of Individual Influence in an Organization. Administrative Science Quarterly, 29, 518-539. doi:10.2307/2392937

Buckley, P. J. (2002). Is the International Business Research Agenda Running out of Steam? Journal of International Business Studies, 33, 365-373. doi:10.1057/palgrave.jibs.8491021

Buckley, P. J. (2009a). The impact of the global factory on economic development. Journal of World Business, 44, 131-143. doi:10.1016/j.jwb.2008.05.003

Buckley, P. J. (2009b). Internalisation thinking: From the multinational enterprise to the global factory. International Business Review, 18, 224-235. doi:10.1016/j.ibusrev.2009.01.006

Buckley, P. J. (2011). International Integration and Coordination in the Global Factory. Management International Review, 51, 269. doi:10.1007/s11575-011-0075-2

Buckley, P. J., \& Casson, M. (1976). The future of the multinational enterprise. London: Macmillan.

Buckley, P. J., Doh, J. P., \& Benischke, M. H. (2017). Towards a renaissance in international business research? Big questions, grand challenges, and the future of IB scholarship. Journal of International Business Studies, 48, 1045-1064. doi:10.1057/s41267-017-0102$\mathrm{Z}$

Buckley, P. J., \& Ghauri, P. N. (2004). Globalisation, economic geography and the strategy of multinational enterprises. Journal of International Business Studies, 35, 81-98. doi:10.1057/palgrave.jibs.8400076

Buckley, P. J., \& Lessard, D. R. (2005). Regaining the Edge for International Business Research. Journal of International Business Studies, 36, 595-599. doi:10.1057/palgrave.jibs. 8400170 
Buckley, P. J., \& Strange, R. (2015). The governance of the global factory: Location and control of world economic activity. Academy of Management Perspectives, 29, 237-249. doi:10.5465/amp.2013.0113

Burt, R. S. (1992). Structural holes: The social structure of competition. Cambridge, MA: Harvard university press.

Burt, R. S. (2000). The Network Structure Of Social Capital. Research in Organizational Behavior, 22, 345-423. doi:10.1016/S0191-3085(00)22009-1

Burt, R. S. (2001). Structural Holes versus Network Closure as Social Capital. In N. Lin, K. S. Cook \& R. S. Burt (Eds.), Social Capital: Theory and Research (pp. 31-56). New Brunswick, NJ: Transaction Publishers.

Cantwell, J., Dunning, J. H., \& Lundan, S. M. (2010). An evolutionary approach to understanding international business activity: The co-evolution of MNEs and the institutional environment. Journal of International Business Studies, 41, 567-586. doi:10.1057/jibs.2009.95

Carter, C. R., Ellram, L. M., \& Tate, W. (2007). The Use of Social Network Analysis in Logistics Research. Journal of Business Logistics, 28, 137-168. doi:10.1002/j.21581592.2007.tb00235.x

Castro, I., \& Roldán, J. L. (2013). A mediation model between dimensions of social capital. International Business Review, 22, 1034-1050. doi:10.1016/j.ibusrev.2013.02.004

Cattani, G., \& Ferriani, S. (2008). A Core/Periphery Perspective on Individual Creative Performance: Social Networks and Cinematic Achievements in the Hollywood Film Industry. Organization Science, 19, 824-844. doi:10.1287/orsc.1070.0350

Cavusgil, S. T., Calantone, R. J., \& Zhao, Y. (2003). Tacit knowledge transfer and firm innovation capability. Journal of Business \& Industrial Marketing, 18, 6-21. doi:10.1108/08858620310458615

Cavusgil, S. T., \& Knight, G. (2009). Born global firms: A new international enterprise. New York: Business Expert Press.

Cavusgil, S. T., \& Knight, G. (2015). The born global firm: An entrepreneurial and capabilities perspective on early and rapid internationalization. Journal of International Business Studies, 46, 3-16. doi:10.1057/jibs.2014.62

Chen, H., \& Chen, T.-j. (1998). Network Linkages and Location Choice in Foreign Direct Investment. Journal of International Business Studies, 29, 445-467. doi:10.1057/palgrave.jibs.8490002

Cheng, J. L. C., Henisz, W. J., Roth, K., \& Swaminathan, A. (2009). From the Editors: Advancing interdisciplinary research in the field of international business: Prospects, issues and challenges. Journal of International Business Studies, 40, 1070-1074. doi:10.1057/jibs.2009.41

Choi, T. Y., Dooley, K. J., \& Rungtusanatham, M. (2001). Supply networks and complex adaptive systems: control versus emergence. Journal of Operations Management, 19, 351-366. doi:10.1016/s0272-6963(00)00068-1

Chua, R. Y. J., Morris, M. W., \& Ingram, P. (2009). Guanxi vs networking: Distinctive configurations of affect- and cognition-based trust in the networks of Chinese vs American managers. Journal of International Business Studies, 40, 490-508. doi:10.1057/palgrave.jibs. 8400422

Coase, R. H. (1937). The Nature of the Firm. Economica, 4, 386-405. doi:10.2307/2626876

Coleman, J. S. (1958). Relational Analysis: The Study of Social Organizations With Survey Methods. Human Organization, 17, 28. 
Coleman, J. S. (1988). Social Capital in the Creation of Human Capital. American Journal of Sociology, 94, S95-S120. doi:10.1016/B978-0-7506-7222-1.50005-2

Cook, K. S., Emerson, R. M., Gillmore, M. R., \& Yamagishi, T. (1983). The Distribution of Power in Exchange Networks: Theory and Experimental Results. American Journal of Sociology, 89, 275-305. doi:10.1086/227866

Coviello, N. E. (2006). The network dynamics of international new ventures. Journal of International Business Studies, 37, 713-731. doi:10.1057/palgrave.jibs.8400219

Cross, R., Parker, A., \& Sasson, L. (2003). Networks in the knowledge economy: Oxford University Press.

Cumbers, A., Nativel, C., \& Routledge, P. (2008). Labour agency and union positionalities in global production networks. Journal of Economic Geography, 8, 369-387. doi:10.1093/jeg/lbn008

Delios, A. (2017). The Death and Rebirth (?) of International Business Research. Journal of Management Studies, 54, 391-397. doi:10.1111/joms.12222

Devinney, T. M., \& Hohberger, J. (2017). The past is prologue: Moving on from Culture's Consequences. Journal of International Business Studies, 48, 48-62. doi:10.1057/s41267$016-0034-\mathrm{z}$

Dhanaraj, C. (2007). Managing the Embedded Multinational: A BusinessNetwork View. Journal of International Business Studies, 38, 1231-1233. doi:10.1057/palgrave.jibs.8400321

Dunning, J. H. (1988). The Eclectic Paradigm of International Production: A Restatement and Some Possible Extensions. Journal of International Business Studies, 19, 1-31. doi:10.1057/palgrave.jibs. 8490372

Ellis, P. D. (2011). Social ties and international entrepreneurship: Opportunities and constraints affecting firm internationalization. Journal of International Business Studies, 42, 99-127. doi:10.1057/jibs.2010.20

Fombrun, C. J. (1982). Strategies for Network Research in Organizations. Academy of Management Review, 7, 280-291. doi:10.5465/amr.1982.4285594

Forsgren, M., Holm, U., \& Johanson, J. (2005). Managing the Embedded MNC: A Business Network View. Northampton, MA: Edward Elgar Publishing.

Forsgren, M., \& Johanson, J. (2014). Managing networks in international business: Routledge.

Frenkel, S., Sanders, K., \& Bednall, T. (2013). Employee perceptions of management relations as influences on job satisfaction and quit intentions. Asia Pacific Journal of Management, 30, 7-29. doi:10.1007/s10490-012-9290-z

Fritsch, M., \& Kauffeld-Monz, M. (2008). The impact of network structure on knowledge transfer: an application of social network analysis in the context of regional innovation networks. The Annals of Regional Science, 44, 21. doi:10.1007/s00168-008-0245-8

García-Lillo, F., Claver-Cortés, E., Marco-Lajara, B., \& Úbeda-García, M. (2017). Mapping the Intellectual Structure of Research on 'Born Global' Firms and INVs: A Citation/Cocitation Analysis. Management International Review, 57, 631-652. doi:10.1007/s11575016-0308-5

Gargiulo, M., Ertug, G., \& Galunic, C. (2009). The Two Faces of Control: Network Closure and Individual Performance among Knowledge Workers. Administrative Science Quarterly, 54, 299-333. doi:10.2189/asqu.2009.54.2.299

Ghoshal, S., \& Bartlett, C. A. (1990). The Multinational Corporation as an Interorganizational Network. The Academy of Management Review, 15, 603-625. doi:10.2307/258684 
Hånell, S. M., \& Ghauri, P. N. (2016). Internationalization of Smaller Firms: Opportunity Development through Networks. Thunderbird International Business Review, 58, 465477. doi:10.1002/tie.21763

Hanneman, R. A., \& Riddle, M. (2005). Introduction to social network methods. In: University of California Riverside.

Henisz, W. J. (2013). Preferences, Structure, and Influence: The Engineering of Consent. Global Strategy Journal, 3, 338-359. doi:10.1111/j.2042-5805.2013.01064.x

Hennart, J.-F. (1982). A theory of multinational enterprise: University of Michigan Press Ann Arbor, MI.

Ho, Y., \& Chiu, H. (2013). A social network analysis of leading semiconductor companies' knowledge flow network. Asia Pacific Journal of Management, 30, 1265-1283. doi:10.1007/s10490-011-9268-2

Holm, D. B., Eriksson, K., \& Johanson, J. (1996). Business Networks and Cooperation in International Business Relationships. Journal of International Business Studies, 27, 1033 1053. doi:10.1057/palgrave.jibs.8490162

Jean, R.-J. B., Tan, D., \& Sinkovics, R. R. (2011). Ethnic ties, location choice, and firm performance in foreign direct investment: A study of Taiwanese business groups FDI in China. International Business Review, 20, 627-635. doi:10.1016/j.ibusrev.2011.02.012

Johanson, J., \& Vahlne, J.-E. (1977). The Internationalization Process of the Firm-A Model of Knowledge Development and Increasing Foreign Market Commitments. Journal of International Business Studies, 8, 23-32. doi:10.1057/palgrave.jibs.8490676

Johanson, J., \& Vahlne, J.-E. (1990). The Mechanism of Internationalisation. International Marketing Review, 7, 11-24. doi:10.1108/02651339010137414

Johanson, J., \& Vahlne, J.-E. (2006). Commitment and opportunity development in the internationalization process: A note on the Uppsala internationalization process model. Management International Review, 46, 165-178. doi:10.1007/s11575-006-0043-4

Johanson, J., \& Vahlne, J.-E. (2009). The Uppsala internationalization process model revisited: From liability of foreignness to liability of outsidership. Journal of International Business Studies, 40, 1411-1431. doi:10.1057/jibs.2009.24

Johanson, J., \& Vahlne, J.-E. (2011). Markets as networks: implications for strategy-making. Journal of the Academy of Marketing Science, 39, 484-491. doi:10.1007/s11747-0100235-0

Kano, L. (2018). Global value chain governance: A relational perspective. Journal of International Business Studies, 49, 684-705. doi:10.1057/s41267-017-0086-8

Kempe, D., Kleinberg, J., \& Tardos, É. (2003). Maximizing the spread of influence through a social network. In Proceedings of the ninth ACM SIGKDD international conference on Knowledge discovery and data mining (pp. 137-146): ACM.

Kilduff, M., \& Brass, D. J. (2010). Organizational Social Network Research: Core Ideas and Key Debates. Academy of Management Annals, 4, 317-357. doi:10.1080/19416520.2010.494827

Kim, Y., Choi, T. Y., Yan, T., \& Dooley, K. (2011). Structural investigation of supply networks: A social network analysis approach. Journal of Operations Management, 29, 194-211. doi:10.1016/j.jom.2010.11.001

Kontinen, T., \& Ojala, A. (2011). Network ties in the international opportunity recognition of family SMEs. International Business Review, 20, 440-453.

doi:10.1016/j.ibusrev.2010.08.002 
Kurt, Y., \& Yamin, M. (2016). Understanding Internationalisation through the Lens of Social Network Analysis. In H. Tüselmann, S. Buzdugan, Q. Cao, D. Freund \& S. Golesorkhi (Eds.), Impact of International Business: Challenges and Solutions for Policy and Practice (pp. 241-264). London: Palgrave Macmillan UK.

Lazzarini, S., Chaddad, F., \& Cook, M. (2001). Integrating supply chain and network analyses: The study of netchains. Journal on Chain and Network Science, 1, 7-22. doi:10.3920/JCNS2001.x002

Lea, B. R., Yu, W. B., Maguluru, N., \& Nichols, M. (2006). Enhancing business networks using social network based virtual communities. Industrial Management \& Data Systems, 106, 121-138. doi:10.1108/02635570610641022

Li, W., Li, P. P., Shu, C., \& Zhou, M. (2015). Ranking and mapping the contributions by overseas Chinese strategy scholars: A systematic and relevant analysis. Asia Pacific Journal of Management, 32, 1085-1108. doi:10.1007/s10490-015-9432-1

Mäkelä, K., Andersson, U., \& Seppälä, T. (2012). Interpersonal similarity and knowledge sharing within multinational organizations. International Business Review, 21, 439-451. doi:10.1016/j.ibusrev.2011.05.003

Marin, A., \& Wellman, B. (2011). Social network analysis: An introduction. In J. Scott \& P. J. Carrington (Eds.), The SAGE handbook of social network analysis (Vol. 11). Thousand Oaks, CA: Sage.

Michailova, S. (2011). Contextualizing in International Business research: Why do we need more of it and how can we be better at it? Scandinavian Journal of Management, 27, 129-139. doi:10.1016/j.scaman.2010.11.003

Mizruchi, M. S., \& Potts, B. B. (1998). Centrality and power revisited: actor success in group decision making. Social Networks, 20, 353-387. doi:10.1016/S0378-8733(98)00009-4

Monaghan, S., Gunnigle, P., \& Lavelle, J. (2014). "Courting the multinational”: Subnational institutional capacity and foreign market insidership. Journal of International Business Studies, 45, 131-150. doi:10.1057/jibs.2013.47

Nahapiet, J., \& Ghoshal, S. (1998). Social Capital, Intellectual Capital, and the Organizational Advantage. The Academy of Management Review, 23, 242-266. doi:10.2307/259373

Odlin, D., \& Benson-Rea, M. (2017). Competing on the edge: Implications of network position for internationalizing small- and medium-sized enterprises. International Business Review, 26, 736-748. doi:10.1016/j.ibusrev.2017.01.003

Otte, E., \& Rousseau, R. (2002). Social network analysis: a powerful strategy, also for the information sciences. Journal of Information Science, 28, 441-453. doi:10.1177/016555150202800601

Parkhe, A., Wasserman, S., \& Ralston, D. A. (2006). Introduction to Special Topic Forum: New Frontiers in Network Theory Development. The Academy of Management Review, 31, 560-568. doi:10.2307/20159228

Peng, M. W. (2004). Identifying the Big Question in International Business Research. Journal of International Business Studies, 35, 99-108. doi: 10.I057/palgrave.jibs.8400077

Peng, M. W., Au, K. Y., \& Wang, D. Y. L. (2001). Interlocking Directorates as Corporate Governance in Third World Multinationals: Theory and Evidence from Thailand. Asia Pacific Journal of Management, 18, 161-181. doi:10.1023/a:1010659722213

Peng, M. W., Sun, S. L., Pinkham, B., \& Chen, H. (2009). The Institution-Based View as a Third Leg for a Strategy Tripod. Academy of Management Perspectives, 23, 63-81. doi:10.5465/amp.2009.43479264

Penrose, E. T. (1959). The Theory of the Growth of the Firm: Oxford university press. 
Reagans, R., \& McEvily, B. (2003). Network Structure and Knowledge Transfer: The Effects of Cohesion and Range. Administrative Science Quarterly, 48, 240-267. doi:10.2307/3556658

Riviere, M., \& Bass, A. E. (2018). How dimensions of internationalization shape the MNE's renewal capability: Multidimensional and multilevel considerations. Long Range Planning. doi:10.1016/j.lrp.2018.12.002

Roth, K., \& Kostova, T. (2003). The Use of the Multinational Corporation as a Research Context. Journal of Management, 29, 883-902. doi:10.1016/s0149-2063_03_00083-7

Rugman, A. M., \& Brain, C. (2003). Multinational Enterprises Are Regional, Not Global. Multinational Business Review, 11, 3-12. doi:10.1108/1525383X200300001

Rugman, A. M., \& Verbeke, A. (2004). A perspective on regional and global strategies of multinational enterprises. Journal of International Business Studies, 35, 3-18. doi:10.1057/palgrave.jibs.8400073

Scott, J. (2013). Social network analysis. London: Sage.

Sinkovics, R. R., Kurt, Y., \& Sinkovics, N. (2018). The effect of matching on perceived export barriers and performance in an era of globalization discontents: Empirical evidence from UK SMEs. International Business Review, 27, 1065-1079. doi:10.1016/j.ibusrev.2018.03.007

Smith, A. R., Ryan, P. A., \& Collings, D. G. (2012). Born global networks: the role of connectors. European Journal of International Management, 6, 566-589. doi:10.1504/ejim.2012.049642

Sparrowe, R. T., Liden, R. C., Wayne, S. J., \& Kraimer, M. L. (2001). Social Networks and the Performance of Individuals and Groups. The Academy of Management Journal, 44, 316325. doi: $10.2307 / 3069458$

Tang, F., \& Xi, Y. (2006). Exploring dynamic multi-level linkages in inter-organizational networks. Asia Pacific Journal of Management, 23, 187-208. doi:10.1007/s10490-0067166-9

Teegen, H., Doh, J. P., \& Vachani, S. (2004). The importance of nongovernmental organizations (NGOs) in global governance and value creation: an international business research agenda. Journal of International Business Studies, 35, 463-483. doi:10.1057/palgrave.jibs. 8400112

Ter Wal, A. L. J., \& Boschma, R. A. (2009). Applying social network analysis in economic geography: framing some key analytic issues. The Annals of Regional Science, 43, 739756. doi:10.1007/s00168-008-0258-3

Turkina, E., \& Van Assche, A. (2018). Global connectedness and local innovation in industrial clusters. Journal of International Business Studies, 49, 706-728. doi:10.1057/s41267-0180153-9

Tüselmann, H., Sinkovics, R. R., \& Pishchulov, G. (2016). Revisiting the standing of international business journals in the competitive landscape. Journal of World Business, 51, 487-498. doi:10.1016/j.jwb.2016.01.006

Uzzi, B. (1997). Social Structure and Competition in Interfirm Networks: The Paradox of Embeddedness. Administrative Science Quarterly, 42, 35-67. doi:10.2307/2393808

Vahlne, J. E., \& Johanson, J. (2013). The Uppsala model on evolution of the multinational business enterprise - from internalization to coordination of networks. International Marketing Review, 30, 189-210. doi:10.1108/02651331311321963 
Verbeke, A., Kano, L., \& Yuan, W. (2016). Inside the regional multinationals: A new value chain perspective on subsidiary capabilities. International Business Review, 25, 785-793. doi:10.1016/j.ibusrev.2016.01.019

Vohra, N., \& Thomas, N. (2016). Investigating Organizational Learning through Social Network Analysis: The Case of a Consultancy Firm in India. Thunderbird International Business Review, 58, 587-600. doi:10.1002/tie.21777

Walker, G., Kogut, B., \& Shan, W. (1997). Social Capital, Structural Holes and the Formation of an Industry Network. Organization Science, 8, 109-125. doi:10.1016/B978-0-7506-7222$1.50013-1$

Wang, S., Dong, B., Si, S. X., \& Dou, J. (2017). When it rains, it pours: A triple-pathway model of collective turnover based on causal mapping analysis. Asia Pacific Journal of Management, 34, 461-486. doi:10.1007/s10490-017-9504-5

Wasserman, S., \& Faust, K. (1994). Social network analysis: Methods and applications. Cambridge, UK: Cambridge university press.

Whelan, E. (2011). It's who you know not what you know: a social network analysis approach to talent management. European Journal of International Management, 5, 484-500. doi:10.1504/ejim.2011.042175

Wu, T., Blackhurst, J., \& O'grady, P. (2007). Methodology for supply chain disruption analysis. International Journal of Production Research, 45, 1665-1682. doi:10.1080/00207540500362138

Yamin, M. (2011). A Commentary on Peter Buckley's Writings on the Global Factory. Management International Review, 51, 285-293. doi:10.1007/s11575-011-0074-3

Yamin, M., \& Kurt, Y. (2018). Revisiting the Uppsala internationalization model: Social network theory and overcoming the liability of outsidership. International Marketing Review, 35, 2-17. doi:10.1108/IMR-11-2014-0345

Zucchella, A., Palamara, G., \& Denicolai, S. (2007). The drivers of the early internationalization of the firm. Journal of World Business, 42, 268-280. doi:10.1016/j.jwb.2007.04.008 


\section{Appendix - Figures and Tables}

Table 1. Visual representation of SNA measures.

\begin{tabular}{|l|l|l|l|}
\hline $\begin{array}{c}\text { Open networks } \\
\text { (structural holes) }\end{array}$ & Network Closure & Centrality & Core-Periphery \\
\hline $\begin{array}{l}\text { Node A occupies a } \\
\text { structural holes position } \\
\text { between otherwise } \\
\text { disconnected groups, } \\
\text { which represent an open } \\
\text { network structure. }\end{array}$ & $\begin{array}{l}\text { All nodes are densely } \\
\text { connected to each other, } \\
\text { representing a closed } \\
\text { network structure. }\end{array}$ & $\begin{array}{l}\text { Node A has the highest } \\
\text { degree centrality with the } \\
\text { highest number of direct } \\
\text { ties. }\end{array}$ & $\begin{array}{l}\text { Nodes within the dotted area } \\
\text { are densely connected and } \\
\text { outer nodes are scarcely } \\
\text { connected, representing a } \\
\text { core/periphery structure. }\end{array}$ \\
\hline
\end{tabular}

Table 2: IB journals reviewed for SNA application

\begin{tabular}{|c|c|c|c|}
\hline Journal & $\begin{array}{l}\text { Number of } \\
\text { articles } \\
\text { using SNA }\end{array}$ & $\begin{array}{l}\text { ABS } 2018 \\
\text { Rank }\end{array}$ & Publisher \\
\hline Journal of International Business Studies (JIBS) & 5 & $4^{*}$ & Palgrave \\
\hline Journal of World Business (JWB) & 0 & 4 & Elsevier \\
\hline Global Strategy Journal (GSJ) & 2 & 3 & Wiley \\
\hline Management and Organization Review (MOR) & 0 & 3 & $\begin{array}{l}\text { Cambridge } \\
\text { Journals }\end{array}$ \\
\hline International Business Review (IBR) & 3 & 3 & Elsevier \\
\hline Management International Review (MIR) & 1 & 3 & Springer \\
\hline Journal of International Management (JIM & 0 & 3 & Elsevier \\
\hline Asia Pacific Journal of Management (APJM) & 6 & 3 & Springer \\
\hline Asia Pacific Business Review (APBR) & 0 & 2 & Taylor \& Francis \\
\hline Thunderbird IB Review (TIBR) & 1 & 2 & Wiley \\
\hline $\begin{array}{l}\text { Critical Perspectives on International Business } \\
\text { (CPolB) }\end{array}$ & 0 & 2 & Emerald \\
\hline Transnational Corporations (TCs) & 0 & 2 & UNCTAD \\
\hline Multinational Business Review (MBR) & 0 & 2 & Emerald \\
\hline $\begin{array}{l}\text { European Journal of International } \\
\text { Management (EJIM) }\end{array}$ & 2 & 1 & Inderscience \\
\hline Journal of Asia Pacific Business (JAPB) & 0 & 1 & Taylor \& Francis \\
\hline Journal of East West Business (JEWB) & 0 & 1 & Taylor \& Francis \\
\hline
\end{tabular}


Table 3: Articles using SNA in international business research

\begin{tabular}{|c|c|c|c|}
\hline Study/Journal & Motivation for Applying SNA & SNA Data & $\begin{array}{c}\text { Software } \\
\text { Applied }\end{array}$ \\
\hline $\begin{array}{l}\text { Turkina and Van } \\
\text { Assche (2018) } \\
\text { JIBS }\end{array}$ & $\begin{array}{l}\text { 'We then combine insights from international } \\
\text { business theory, economic geography, and } \\
\text { social network analysis to evaluate how a } \\
\text { cluster's relative position in the global cluster } \\
\text { network relates to (1) the type of value chain } \\
\text { activities in which it specializes, and (2) the } \\
\text { type of international organization-based } \\
\text { linkages that disproportionately strengthens } \\
\text { local innovation.' (p.707). }\end{array}$ & $\begin{array}{l}\text { Longitudinal } \\
\text { dataset on formal } \\
\text { linkages between a } \\
\text { network of cluster } \\
\text { firms }\end{array}$ & $\begin{array}{c}\text { Regression } \\
\text { analysis }\end{array}$ \\
\hline $\begin{array}{l}\text { Devinney and } \\
\text { Hohberger } \\
(2017) \\
\text { JIBS }\end{array}$ & $\begin{array}{l}\text { 'We...visualized and analyzed the results via } \\
\text { social network analysis' (p. 50) } \\
\text { 'Network methods [SNA] are generally } \\
\text { accurate and effective... and allow the display } \\
\text { of a larger number of documents in } \\
\text { meaningful ways' (p. 61). }\end{array}$ & $\begin{array}{l}\text { Coupling } \\
\text { proximity scores }\end{array}$ & GEPHI \\
\hline $\begin{array}{l}\text { Monaghan, } \\
\text { Gunnigle, and } \\
\text { Lavelle (2014) } \\
\text { JIBS }\end{array}$ & $\begin{array}{l}\text { '[U]sing quantitative social network analysis [...] } \\
\text { allowed a greater visually generated empirical } \\
\text { exploration of the structural and relational } \\
\text { patterns under review' (p.137) } \\
\text { 'Social network analysis was employed to further } \\
\text { substantiate the composition of this institutional } \\
\text { network and to explore the relative centrality of } \\
\text { actors more effectively' (p.138). }\end{array}$ & $\begin{array}{l}\text { Quantitative } \\
\text { data collected } \\
\text { through social } \\
\text { network } \\
\text { questionnaires }\end{array}$ & UCINET \\
\hline $\begin{array}{l}\text { Chua, Morris, } \\
\text { and Ingram } \\
\text { (2009) } \\
\text { JIBS }\end{array}$ & $\begin{array}{l}\text { 'The current research used methods of social } \\
\text { network analysis to investigate trust as a } \\
\text { differentiating dimension between Chinese and } \\
\text { Western networks' (p. 503). }\end{array}$ & $\begin{array}{l}\text { Egocentric } \\
\text { network data } \\
\text { collected } \\
\text { through } \\
\text { network } \\
\text { surveys }\end{array}$ & $\begin{array}{l}\text { Random } \\
\text { effects } \\
\text { regression } \\
\text { analysis }\end{array}$ \\
\hline \multirow[t]{2}{*}{$\begin{array}{l}\text { Coviello (2006) } \\
\text { JIBS }\end{array}$} & $\begin{array}{l}\text { 'As changes in network structure are expected to } \\
\text { cause changes in the venture's social capital } \\
\text { (Borgatti et al., 1998; Burt, 2000), analysis } \\
\text { focused on the key structural dimensions of the } \\
\text { network and patterns of structural change' (p. } \\
719 \text { ). 'UCINET } 6 \text { was used to compute network } \\
\text { range, network density, closeness centrality and } \\
\text { betweenness centrality of international new } \\
\text { ventures' (pp.719-720). }\end{array}$ & $\begin{array}{l}\text { Transforming } \\
\text { each firm's } \\
\text { chronology } \\
\text { into network } \\
\text { matrices }\end{array}$ & UCINET \\
\hline & $\begin{array}{l}\text { '[W]e will explore whether the roles and the } \\
\text { positions of countries in the network are related }\end{array}$ & $\begin{array}{l}\text { IMF dataset to } \\
\text { identify the } \\
\text { structure and }\end{array}$ & UCINET \\
\hline
\end{tabular}




\begin{tabular}{|c|c|c|c|}
\hline $\begin{array}{l}\text { Bolívar, } \\
\text { Casanueva, and } \\
\text { Castro (2019) } \\
\text { IBR }\end{array}$ & $\begin{array}{l}\text { to their trade expansion and development } \\
\text { performance' (p.697) }\end{array}$ & $\begin{array}{l}\text { the topology of } \\
\text { the Global FDI } \\
\text { Network }\end{array}$ & \\
\hline $\begin{array}{l}\text { Castro and } \\
\text { Roldán (2013) } \\
\text { IBR }\end{array}$ & $\begin{array}{l}\text { 'The study uses SNA in order to analyze the } \\
\text { structural dimension of inter-organizational } \\
\text { networks through focusing on centrality } \\
\text { measure[s]' (p. 1041). }\end{array}$ & $\begin{array}{l}\text { Secondary } \\
\text { relational data } \\
\text { was collected } \\
\text { from the Public } \\
\text { Works } \\
\text { Financing } \\
\text { database }\end{array}$ & UCINET \\
\hline $\begin{array}{l}\text { Mäkelä, } \\
\text { Andersson, and } \\
\text { Seppälä (2012) } \\
\text { IBR }\end{array}$ & $\begin{array}{l}\text { To understand how structural boundaries } \\
\text { influence knowledge exchanges. }\end{array}$ & $\begin{array}{l}\text { Network data } \\
\text { obtained } \\
\text { through name } \\
\text { generator } \\
\text { technique }\end{array}$ & $\begin{array}{l}\text { Multilevel } \\
\text { analysis } \\
\text { using } \\
\text { general } \\
\text { linear } \\
\text { regression }\end{array}$ \\
\hline $\begin{array}{l}\text { García-Lillo, } \\
\text { Claver-Cortés, } \\
\text { Marco-Lajara, } \\
\text { and Úbeda- } \\
\text { García (2017) } \\
\text { MIR }\end{array}$ & $\begin{array}{l}\text { 'The research developed here through the use of } \\
\text { citation and co-citation analysis and social } \\
\text { networks analysis allowed us to examine and } \\
\text { represent the structure or intellectual base of } \\
\text { research on the phenomenon of born global firms } \\
\text { or international new ventures (INVs)' (p. 645) }\end{array}$ & $\begin{array}{l}\text { Co-citation } \\
\text { matrix }\end{array}$ & $\begin{array}{l}\text { BIBEXCEL } \\
\text { and PAJEK }\end{array}$ \\
\hline
\end{tabular}

\section{Henisz (2013) I add insight from social network analysis} GSJ
(Wasserman and Faust, 1997) to better represent stakeholders as embedded in a network structure that both enables and constrains their behavior' (p. 341).

$\begin{array}{ll}\text { Stakeholder } & \text { Simulation } \\ \text { data } & \text { Analysis }\end{array}$

Awate, Larsen, 'We then conduct a comparative network analysis and Mudambi (2012) GSJ along the breadth and depth of the knowledge bases to shed light on how Suzlon's innovation capabilities differ with respect to Vestas' (p. 209).
Backwardcited patents data
Wang, Dong, Si, and Dou (2017) APJM
'In step two, social network analysis (UCINET; Borgatti, Everett \& Freeman, 2002) was used to identify the key elements in each type based on their degree centrality and betweenness centrality' (p. 467).
Collective turnover events data
UCINET

\section{UCINET}

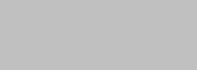


'In order to test $\mathrm{H} 3$, which posits $\mathrm{HR}$-line

Frenkel, Sanders, and Bednall

(2013)

APJM

management relations as a moderator in the relationship between extent of agreement between

SM and LM relations and the two employee outcomes, we add HR-LM relations as measured in the social network analysis and the interaction between this variable and the extent of agreement between SM and LM relations' (p. 19).

$\begin{array}{ll}\begin{array}{l}\text { Ho and Chiu } \\ \text { (2013) }\end{array} & \begin{array}{l}\text { 'Social network analysis and theory help us not } \\ \text { only delineate the individual actors in the } \\ \text { APJM }\end{array} \\ \begin{array}{l}\text { knowledge flow network but also to determine } \\ \text { network ties, relations, frequency, and density' } \\ \text { (p. 1266). }\end{array} \\ \begin{array}{l}\text { Tang and Xi } \\ \text { (2006) }\end{array} \\ \begin{array}{l}\text { '[W]e compared network positions using } \\ \text { Stephenson and Zelen's (1989) information } \\ \text { centrality measure, which calculates centrality } \\ \text { based on all possible paths and takes into } \\ \text { consideration the weight of the relation, using the } \\ \text { UCINET network analysis package' (p. 196). }\end{array}\end{array}$

\section{Quantitative data collected through social network questionnaires}

\section{Patent data from USPTO (US Patent and Trademark Office) patent database \\ UCINET}

Symmetrized data based on the average of the estimates of interaction by each member in the network

UCINET

Published

UCINET archival data
Wang (2001) APJM
'Exploring interlocking directorates allows researchers to "map" out the interorganizational network of corporate governance' (p. 162).
Smith, Ryan, and Collings (2012) EJIM
'[T]his research seeks to make a contribution methodologically, by using social network analysis and interview techniques to investigate how external knowledge emerges with rapid internationalising born globals' (p. 574).

Semi-
structured
interviews

'To aid in the identification and management of Whelan (2011) EJIM talented employees in knowledge intensive settings, this paper proposes an approach based on social network analysis (SNA) - a methodology that analyses the relationships of actors, such as employees, in a network context' (p. 485).
Quantitative data collected through social network questionnaires

\section{UCINET}

1

(n)


social network analysis as a method to study organizational learning' (p. 588). network

questionnaires

Figure 1: SNA and internationalization: an illustrative example

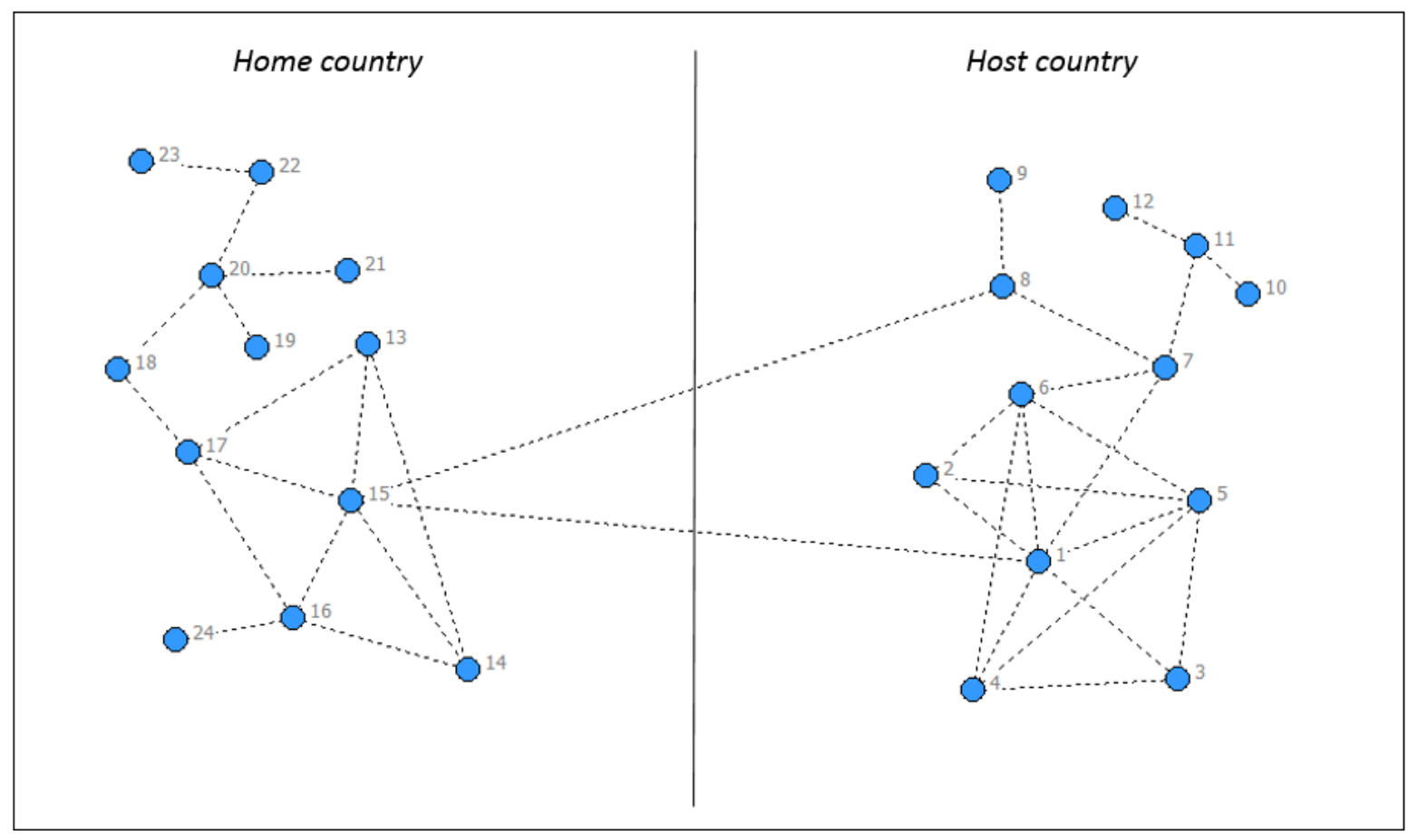

